\title{
A PRATTICA DA LEITURA SEGUNDO "D. QUIXOTE"
}

\section{I}

Se a comparação não fosse exagerada (e ela é), talvez pudéssemos dizer que Cervantes, como D. Quixote, esteve um pouco ao sabor da aventura quando escreveu as façanhas do seu fidalgo. Não é incomum que as coisas mudem de direção no $D$. Quixote, às vezes insidiosamente, algumas outras com uma franqueza desconcertante.

Se quiséssemos começar pelos indícios mais palpáveis, poderíamos lembrar que não foram poucos os estudiosos que descobriram em D. Quixote o herói de face pelo menos dupla e em Cervantes o narrador que devolve com uma das mãos o que retirou com a outra . Lukács não pretende dizer uma verdade desconhecida quando afirma a coexistência em D. Quixote de uma "irresistível comicidade" e uma "comovente nobreza". Esta duplicidade também não escapou a Pirandello, que procurou integrá-la aos efeitos produzidos sobre o leitor. Num rápido esboço dos valores que norteiam o percurso de $\mathrm{D}$. Quixote - aspiração à justiça, proteção aos fracos e combate aos poderosos, vingança à violência e dever do sacrifício - Pirandello pode duvidar da oportunidade de fazer desta figura o pretexto para a desqualificação satírica da cavalaria. E pergunta-se, então, expressando apenas a experiência de qualquer leitor menos desavisado: "Onde se encaixa então a sátira? Nós todos amamos este cavaleiro virtuoso e se suas infelicidades nos fazem rir, elas também nos comovem profundamente" (1).

De resto, esta ambiguidade - nascida das contradições do herói e desconcertante para o leitor desde as primeiras impressões — não é descartada pelo próprio narrador, cuja intenção não se confina à facilidade do riso satírico. Por isso Lukács declara com muita razão que "Cervantes tinha plena consciência tanto do fato de que os ideais do seu herói eram historicamente ultrapassados, postos de lado pela história, quanto da pureza humana, da honestidade subjetiva e do heroísmo de D. Quixote. Ele comprendeu e valorizou corretamente ambos os aspectos" (2).

(1) PIRANDELLO, Luigi - "L'Arioste et Don Quichotte". In Ecrits sur le Théâtre et la Littérature, Paris, Denoel-Gonthier, 1968, p. 111.

(2) LUKÁCS, Georg - "Marx et le Problème de la Décadence Idéologique". In Problèmes du Réalisme, Paris, L'Arche, 1975, p. 224. 
Ainda assim, entretanto, não parece ilegítimo perguntar sobre o momento em que se dá essa descoberta e sua justa distribuição de pesos. Será que Cervantes já tinha topado com ela de antemão, fazendo justiça à sua importância antes mesmo de depositar a primeira palavra sobre o papel?

Também não foram poucos os que entreviram a possibilidade de responder negativamente a esta questão. Estudando o aparecimento do humor na literatura sob o maneirismo, Hauser qualifica D. Quixote como exemplo do herói simultâneamente "louco" e "santo", perante quem seu cronista guardaria certas distâncias. "O humor, continua Hauser, expressa uma atitude dialética, um ponto de vista flexível, susceptível de evolução, retificável a todo momento" (3).

O convívio mais direto com o texto também ensina algo acerca desta prática sujeita a seus desvios. Chklovsky, por exemplo, verifica na obra a existência de uma "concepção primitiva" sobre D. Quixote, dada nas primeiras páginas do livro e revista à medida das aventuras, através dos discursos pronunciados pelo herói.O fidalgo "desinteligente", de juízo rematado, adquire assim uma fina sabedoria, inteiramente imprevista a princípio (4). Por isso, Menéndez Pidal não hesita em usar o termo apropriado, declarando que Cervantes "corrige" o tipo quixotesco. Esta correção entretanto, não é anterior à impressão do livro, não permanece confinada à liberdade do dizer e desdizer própria do manuscrito: depositada francamente aos olhos do leitor, ela se faz visível à medida da própria leitura.

Sob estas voltas e reviravoltas que o sujeitam às retificações, o texto de Cervantes testemunha contra as intenções de assimilar a atividade do escritor à criação divina. Em D. Quixote, os vestígios deixados não permitem entrever a astúcia do demiurgo oculto: nada sugere a monotonia e a limpidez do Gênesis. Nem todas as coisas estão nos seus devidos lugares, ou melhor, todas estão - mas sob regras que não as da harmonia ilusória.

A própria natureza da relação entre sabedoria e loucura em $\mathrm{D}$. Quixote talvez seja um dos tantos indícios valiosos para esta estratégia de pesquisa. Quanto a este tema, Auerbach fez notar como sensatez e doidice coexistem "lado a lado" em D. Quixote, o que não deixa lugar para um tipo de "combinação especificamente shakesperiana e romântica de sabedoria e loucura, na qual uma coisa é incon-

(3) HAUSER, Arnold - El Manierismo, Crisis del Renascimiento, Madrid, Ed. Guadarrama, 1971, p: 319. O grifo é nosso,

(4) CHKLOVSKY, Victor - "Comment est Fait Don Quichotte". In Sur la Théorie de la Prose, Paris, Editions L'Age d'Homme, 1973. 
cebível sem a outra". A combinação se faz muito mais por aglutinação dos elementos, quase ao sabor das aventprras e dos efeitos de comicidade, como quer Auerbach, o que nos remete outra vez a uma prática romanesca exposta ao imprevisto, capaz de correções e distorções. Cervantes não exerce por antecipação qualquer mando divino sobre D. Quixote e Sancho. Não os faz, diz Auerbach - eles se fazem nas suas mãos (5).

Estes avanços e recuos promovidos pelo texto talvez nos forneçam uma perspectiva diferente para enfrentar o debate sobre o estatuto de $D$. Quixote em relação às chamadas novelas de cavalaria .

Em geral, a discussão circula a partir dos polos opostos de duas perguntas extremas. Em termos de pouco rigor, ainda que bastante expressivos, a questão se formularia assim: D. Quixote promoveu a ruína dos ideais da cavalaria, conforme os lamentos de Byron, ou a acreditar em Menéndez Pelayo, retomou-os pela transfiguração? Não é difícil deduzir as implicações contidas em cada uma das alternativas. Seria legítimo, de fato, afirmar que o livro de Cervantes, através de uma operação de inversão, reproduz uma epopéia de cavalaria às avessas, o que conferiria às suas declarações de oposição apenas e tão somente um estatuto de exterioridade? De certo modo, partindo de outra pergunta, alguns responderam negativamente a esta e encararam $D$. Quixote como inauguração de uma nova tradição narrativa, pensada, na via hegeliana, como o grande sucedâneo da epopéia homérica.

Inútil estabelecer um recenseamento de traços isolados, que eventualmente confirmariam ora uma, ora outra das teses do debate. E certo, por exemplo, que a estrutura do entrecho permite digressões narrativas à ação principal, à maneira dos textos de cavalaria: o achado de um manuscrito ou o serão casual com personagens episódicas permitem a introdução de pequenas estórias, marginais, cuja proliferação será criticada, mais tarde, pelo próprio D. Quixote. Por outro lado, se a idéia de romance está ligada à vontade de contar a história de uma vida individual, nisto o livro de Cervantes ultrapassa os propósitos da novela de cavalaria, interessada sobretudo em multiplicar as aventuras, importando menos ou nada as figuras que as viveram - o que ajuda a explicar a produção em massa dos séculos XV e XVI: Amadís de Gaula foi pai de Esplandián, que foi pai de Lisuarte, que foi pai de Amadís de Grécia, que foi pai de Florisel de Niquéia. D. Quixote é o imitador fiel do iniciador desta dinastia

(5) AUERBACH, Erich - "A Dulcinéia Encantanda". In Mimesis, São Paulo, Ed. Perspectiva-Ed. da Universidade de São Paulo, 1971, pp. 292-314. Sob certas reservas, uma combinação semelhante talvez possa ser assimilada à loucura sábia do Licenciado Vidriera . 
generosa, mas não é um mero instrumento para o leitor se embriagar em aventuras maravilhosas. Ao contrário, o leitor não passa incólume por ele, debruça-se sobre D. Quixote e sobre Sancho Pança, perscruta-lhes a evolução: tantas vezes repetido, o modelo da relação cavaleiro-escudeiro não saberia caber aqui.

Todas estas discordâncias e concordâncias com o texto de cavalaria têm sem dúvida a sua importância, mas no devido tempo. Acreditamos alcançar uma eficácia teórica mais ampla, se integrarmos estes elementos a uma pesquisa mais abrangente, que se pergunte, por exemplo, pelo comportamento de leitura exigido por $D$. Quixote do seu leitor. Em que esta relação de leitura se distingue da proposta contida na novela de cavalaria? Repete-a Cervantes através de uma operação de mera inversão do enfoque ideológico dos valores cavalheirescos? A inversão, entretanto, não implicaria em recusa? Mas se o que temos pensado não é ilusório, se realmente $D$. Quixote se produz como um texto sujeito a retificações, a introdução de questões que advertissem para certas nuances de ordem temporal não seria assim tão fora de propósito. A pergunta se formularia, então, em outros termos, levando em conta a idéia de composição por desvio: quando Cervantes simplesmente reproduz a relação de leitura anterior e quando efetivamente a subverte?

\section{I}

A propósito do auto-espelhamento da narrativa em $D$. Quixote e outros textos, perguntando-se pela estranheza provocada por tais efeitos de desdobramento, J.-L. Borges arrisca a conclusão de que as "inversões sugerem que se os caracteres de uma ficção podem set leitores ou espectadores, nós, seus leitores ou espectadores, podemos ser fictícios" (6). Muito mais que metáfora inconsequente ou simples exercício de elegância, a declaração de Borges merece talvez uma leitura literal. De fato, a prática da leitura nos torna, ao pé da letra. uma ficção. Durante seu percurso, abdicamos de uma condição empírica, assumimos um lugar e aceitamos a imposição de um papel. Conforme declara W. Kayser, "o leitor é uma criação fictícia, um papel no qual podemos entrar $(. .$.$) . O começo desta transforma-$ ção permanece habitualmente inconsciente; ela começa quando lemos no subtítulo de um livro a palavra 'romance'; ou talvez desde que se opera a magia da encadernação: os romances não têm o mesmo formato nem o mesmo aspecto geral que as obras científicas ou de propaganda" (7). Encarado como "princípio constitutivo do estilo ro-

(6) BORGES, J.-L. - "Magías Parciales del 'Quijote' ". In Otras Inquisiciones, Buenos Aires, Emecé Editores, 1970, pp. 68-9.

(7) KAYSER, Wolfgang - "Qui Raconte le Roman?". In Poétique, Paris, Seuil, 1970, n⿳ 4, pp. 502 e 504. 
manesco", o leitor não passa incólume da leitura do Werther à leitura de Ulysses. Se estes textos promovem diferentes relações de leitura, o leitor de um e outro já não será o mesmo, embora os mesmos olhos contemplem "a magia da encadernação" e leiam em ambos os subtítulos o aviso "romance" (8).

Diderot costumava explicitar insistentemente esta condição ao fazer do leitor uma espécie de reverso da medalha que traz a cara de uma personagem mais familiar e evidente: o narrador. A tematização desta relação apenas reafirmava o que a prática da literatura descobrira pelo menos desde o Decameron de Bocaccio: o fato de alguns personagens do livro serem tão leitores quanto nós já sugere a concepção do leitor como ficção. Entretanto, a teoria da arte e da literatura não se deu conta desta evidência por muito tempo, ajudada sobretudo pela evolução que principia no século XVIII, quando o romance assume a intenção de convencer os leitores de que a ficção é real.

Neste sentido, o próprio exemplo de Diderot é instrutivo, já que, apesar dos pesares, ele foi um dos arautos entusiasmados desta transformação. Em 1761, em nome da bondade, da beleza, da natureza e da verdade, Diderot saudava a incorporação do cotidiano no romance de Richardson e advertia para o seu correlato necessário: o ilusionismo e a identificação do leitor:

"O mundo onde nós vivemos é o lugar da cena; o fundo do seu drama é verdadeiro; suas personagens têm toda a realidade possível; seus caracteres são tomados do meio da sociedade; seus incidentes fazem parte dos costumes de todas as nações policiadas; as paixões que ele pinta são tais que eu as experimento em mim; são os mesmos objetos que as comovem, elas têm a energia que thes conheço; os reveses e as aflições de suas personagens são da mesma natu:eza dos que me ameaçam sem cessar; ele me mostra o curso geral das coisas que me rodeiam. Sem esta arte, minha alma se dobraria penosamente sobre vieses quiméricos, a ilusão seria apenas momentânea e a impressão fraca e passageira." (9).

(8) Ê claro que não se pretende assumir aqui uma concepção idealista do leitor e da leitura, que resistisse às diferentes circunstâncias históricas . Afinal, seria um pouco fora de propósito defender tal idéia e falar sobre D. Quixote, sujeito a múltiplas leituras desde o século XVII. Não seria inútil lembrar, portanto, que cada época "se acomoda" segundo exigências específicas a uma certa lógica de leitura inscrita no próprio texto.

(9) DIDEROT - "Eloge de Richardson". In Oeuvres, Paris, Pléiade, 1951, p. 1061 . 
No fundo, Diderot saúda em Richardson o correlato romanesco de sua própria reforma dramática, onde todas as inovações passam pela cotidianização da cena e conduzem a um aperfeiçoamento (ou adaptação às necessidades do tempo) de uma dramaturgia aristotélica, obsecada pela idéia de "quarta parede". O comportamento do espectador no novo drama do século XVIII deve ser da mesma natureza que o dos leitores de Richardson, descritos por Diderot em várias anedotas. Tal senhora de suas relações, "de um gosto e de uma sensibilidade pouco comuns", saúda tais e tais personagens atravé: de alguém que visita a Inglaterra. Duas outras leitoras rompem definitivamente seus laços de amizade, apesar das diligências de Diderot para reconciliá-las, "porque uma desprezava a história de Clarisse, diante da qual a outra estava prosternada". Um terceiro testemunho define com precisão este novo tipo de leitor:

"Eu estava com um amigo quando me remeteram o enterro e o testamento de Clarisse, dois trechos que o tradutor francês suprimiu, sem que se saiba bem por que. Este amigo é um dos homens mais sensíveis que conheço e um dos mais ardentes fanáticos de Richardson: pouco falta para que não o seja tanto quanto eu. Ei-lo que se apodera dos cadernos, que se retira para um canto e que lê. Eu o examinava: primeiro vejo correr lágrimas, ele se interrompe, soluça; de repente se levanta, anda sem saber para onde vai, lança gritos como um homem desolado e dirige as censuras mais amargas a toda a família dos Harlowe." (10).

Os exemplos de Diderot definem com precisão a condição deste leitor produzido a partir do século XVIII: trata-se sobretudo de um sensível. Como bem observa Kayser, a advertência do Werther estabelece as regras do jogo e "define claramente a atitude que deve adotar o leitor": é preciso que se trate antes de mais nada de uma "alma sensível", como diria Goethe em outro lugar. Desta alma se solicita que não negue "lágrimas" ao destino de Werther e a ela se conceda "consolo" pela sua paixão. Não por acaso se diz que a publicação de Werther provocou nos seus leitores a repetição do gesto suicida do herói. O fato ilustra bem o tipo de leitor que domina toda a primeira metade do século XIX, nascido nas primeiras décadas do século anterior: seu papel, então, (fictício, afinal de contas) é o de assumir a arte como se ela fosse a vida, encarar o autor como testemunha de acontecimentos reais, amar ou odiar as personagens como se elas fossem de carne e osso. E como imaginar que as coisas pudessem se passar de outra maneira se Balzac, como lembra Hauser, se referia às suas personagens como se falasse de amizades pessoais?

(10) Idem, ibidem, p. 1071. 
Este leitor, entretanto, não é radicalmente novo. É fácil apontar seu precursor histórico no leitor de cavalaria, do qual D. Quixote é modelo e apoteose. Não é inútil lembrar a afirmação de Hauser de que a alegoria, o símbolo ou a fábula cavam uma certa distância entre o herói e o leitor da novela de cavalaria, distância abolida no século XVIII pela introdução do prosaico na literatura (11). Mas não é fácil ter a medida destas distâncias: o que conta é o real que convence e no qual se acredita, e a Idade Média tinha o seu. A não ser assim, como explicar a figura de Agnolo di Ser Gherardo no século $\mathrm{XIV}$, personagem de Sacchetti, atacado de "monomania cavalheiresca", montando seus setenta anos num cavalo esquálido e percorrendo a distância de Florença a um povoado vizinho para participar de suas justas? Como entender a bizarrice de um estudante de Salamanca, contada pela boca do povo, e segundo quem a mania dos livros de cavalaria o fazia deixar as suas lições e interromper a leitura "com grandes brados e cuteladas no ar em defesa de uma das personagens da novela lida, que até tal ponto lhe sorvia o juízo?” (12). Como explicar, afinal, o próprio D. Quixote, este fidalgo pacato e de boas maneiras, condenado, entretanto, à leitura perpétua, lendo a cavalaria na própria vida?

"Em seu tempo, declara Hauser em outra parte, os antigos poemas heróicos eram cantados, as chansons de geste recitadas e, provavelmente, a antiga epopéia cortesã era lida em público; mas os romances de amor e aventuras são escritos para a leitura privada, sobretudo das damas" (13). Por ora, não nos interessa esta feminilização do público leitor que, de resto, deita raízes mais longínquas na cultura do tempo e interessa a um estudo sociológico mais acurado. O que conta aqui e define o alcance da condição do leitor cavalheiresco é esta intimidade perigosa da leitura solitária, intimidade que a invenção da imprensa virá multiplicar e disseminar por toda parte.

"O leitor de romance é solitário", afirma com razão Walter Benjamin, que logo em seguida adverte para as consequências deste contato que não espera mais as ocasiões públicas, produzido e reproduzido à vontade dos lazeres: "Nesta solidão o leitor de romance se apodera da matéria que lhe é oferecida mais avidamente que ninguém. Ele quer se apropriar dela inteiramente e de alguma forma nela sub-

(11) Ver HAUSER, Arnold - História Social de la Literatura y el Arte, Madrid, Guadarrama, 1969, Vol. II, p. 240.

(12) MENÉNDEZ PIDAL, Ramón - "Un Aspecto de la Elaboración del 'Quijote"' In De Cervantes y Lope de Vega, Madrid, Espasa-Calpe, S. A., 1973, p. 20.

(13) HAUSER, Arnold - Historia Social..., Vol. I, p. 293. 
mergir" (14). E a esta intimidade que o romancista medieval dirige sua astúcia persuasiva e tece com paciência sua rede ilusionista. Desde Chrétien de Troyes, o comportamento do público é sintomático de que o leitor assume o papel proposto: "Todo o mundo ocidental aceita, incorpora e celebra os relatos da matéria Bretanha, que se impõem de tal maneira que transcendem as artes plásticas, se refletem na vida diária e até cedem o nome de seus heróis a pessoas que são batizadas com os nomes de Arthur, Genebra, Tristão, Parsifal, etc." (15).

A propósito deste "romance", (e não é descabido chamá-lo de realista à sua maneira) P. Y. Badel esboça sumariamente um quadro dos seus truques ilusionistas. A descrição dos trajes e interiores, por exemplo, é levada a cabo com um zelo realista minucioso, o que concede à narração do maravilhoso uma "verdade" que ela não teria sem esta providencial ajuda do mundo cotidiano. Desde então, muito antes do sonho astuto do século XIX, o autor finge a objetividade que o traz à condição de testemunha: assim são mandados à tona, indiretamente, os sentimentos das personagens através de uma notação zelosa e aparentemente gratuita de certos gestos e comportamentos; em nome da mesma intenção, o ângulo de visão do narrador se estreita e descreve o mundo a partir da instância das personagens; ou então, solução extrema, reduz-se a zero a presença da autoria, por meio da recorrência ao discurso direto, que dispõe cara a cara o leitor e a personagem.

Até mesmo as aparições do autor procuram não atrapalhar o jogo de duplicação do mundo, tratando-se ainda de um ardil de persuasão, como os anteriores: "Por reflexões irônicas, por entonações maliciosas, o romancista guarda suas distâncias em relação às personagens. Não para mostrar que ele manipula o jogo por trás, mas para colocar suas criaturas como seres autônomos. Ele se volta em direção do leitor para tomá-lo como testemunha, para sorrir com ele destes seres que finge não conhecer" (16).

A estas observações de Badel não seria inútil acrescentar outras e lembrar, por exemplo, o cuidado com que os narradores de $\mathrm{O} \mathrm{Ca}$ valeiro do Cisne, $O$ Cavaleiro Cifar ou Amadís de Gaula escondem a realidade do leitor e da leitura, fazendo apelos a um auditório fic-

(14) BENJAMIN, Walter - "Le Narrateur". In Poésie et Révolution, Paris, Denoel, 1971, p. 159.

(15) RIQUER, Martín de - "Introdución a la Lectura del 'Quijote". In

Don Quijote, Barcelona, E. Labor, 1969, 3.a ed., Vol. I, p. XII
BADEL, P. Y. - Introduction à la Vie Littéraire du Moyen Age, Pa-
ris, Bordas, 1973, p. 191. ris, Bordas, 1973, p. 191. 
tício, como se o leitor fosse um ouvinte e o narrador um contador de viva voz. A narrativa traz ainda na memória os traços da relação imediata entre o poema épico e seu público: "como dijimos", "así como adelante oiredes", "como ya oísteis", declaram os narradores como se falassem aos "ouvintes devotos" (Hauser) do poema épico.

E claro que as coisas nem sempre caminham retilineamente na mesma direção. Se assim fosse, o leitor do Amadís não teria oportınidade de abrir sua leitura com tal advertência:

"Aquí comienza el primero libro del esforzado y virtuoso Caballero Amadís, hijo del Rey Perión de Gaula y de la Reina Helisena, el cual fué corregido y emendado por el honrado y virtuoso Caballero Garci-Rodríguez de Montalvo, regidor de la noble villa de Medina del Campo, y corregióle de los antiguos originales que estaban corruptos y mal compuestos en antiguo estilo, por falta de los diferentes y malos escritores. Quitando muchas palabras superfluas y poniendo otras de más polido y elegante estilo tocantes a la Caballería y actos della." (17).

Mas a partir daqui, nenhum sinal que o distancie das peripécias inventadas e não o deixe esquecer a ênfase da advertência para o livro e a leitura - este jogo estranho que diz respeito ao mundo, mas não é o próprio mundo.

A própria evolução do gênero na Idade Média, lê-se em Badel, testemunha esta vontade de aperfeiçoar um instrumento para fazê-lo mais capaz de elevar os valores particulares de uma classe à altura de verdades universais (18). Do verso à prosa e da prosa em terceira pessoa ao relato autobiográfico, o que se busca, em última instância, é a adesão fácil do leitor a estas verdades. Destas evoluções, a que conduz à prosificação do romance parece ser mais rica em sintomas: a legitimação é buscada na forma em que se exprime a verdade por excelência - a historiografia. "Os romances, aliás, são então muitas vezes chamados estoires. Estoire é a narração de um acontecimento às vezes muito antigo, mas que se inscreveu efetivamente

(17) "Amadís de Gaula". In Libros de Caballerías Hispánicos (estudio, antología y argumentos de José Amezcua), Madrid, Ed. Alcalá, 1973, pp. 151-2 .

(18) Não é inútil lembrar que, em última instância, o romance é instrumento de afirmação de uma nova aristocracia, a cavalheiresca, que não pode exibir garantias de nascimento frente à Ig:eja e aos vilóes (camponeses e burgueses). Ver Hauser e Badel. 
no tempo. A palavra tem, além disso, uma conotação religiosa: a estoire por excelência é a história santa, a do povo judeu, história verdadeira que os clérigos opunham às fábulas forjadas pelos poetas. Ora, no século XIII, mais que nunca, não há um romancista que não recuse para sua obra o nome de fábula. Todos pretendem à verdade da estoire e para isto multiplicam os processos que a tornam natural" (19).

\section{I I}

Quando Cervantes publica em 1605 o primeiro volume de $D$. Quixote, esta relação de leitura está plenamente consagrada em toda a Europa, garantida sobretudo pela invenção da imprensa. Sabe-se que de 1508 a 1589 é possível contar 30 edições do Amadís de Gaula. O próprio $D$. Quixote ganha aceitação imediata e fulminante, como testemunha, se não quisermos voltar à estatística, a publicação apócrifa de Avellaneda, adiantando-se ao segundo volume de Cervantes.

Ā grande ruptura narrativa do século XVI na Espanha, expressa pela chamada novela picaresca, não ocorre romper com esta relação aristotélica de leitura. "No Lazarillo, afirma com razão Américo Castro, sentimos a ilusâo de contemplar a própria vida sem nenhum intermediário: aparece aí um indivíduo que nos convida, sem mais, a penetrar em sua intimidade, a contemplá-la desde o interior de sua própria experiência" (20). "Yo, señor, soy de Segovia", declara à queima-roupa o narrador de $E l$ Buscón, repetindo o fingimento do contador em voz alta. A novela picaresca consagra definitivamente o relato em primeira pessoa, dirigido agora a um ouvinte (leitor) único e individualizado: ao acentuar as individualizações, o processo reforça as consequências (21).

Não é possível esquecer, por outro lado, que na novela picaresca a oposição aos valores cavalheirescos não ultrapassa o plano do suposto. Em D. Quixote, porém, este projeto de desqualificação deixa a sombra e ganha o nível das intenções explícitas. Esta passagem não autorizaria a hipótese de que no texto de Cervantes a negação da cavalaria não é apenas um propósito exterior — que produziria um "romance" medieval invertido — mas implica na desquali-

(19) BADEL, in ob. cit., pp. 196-7.

(20) CASTRO, Américo - "El 'Lazarillo de Tormes'”. In Hacia Cervantes, Madrid, Taurus Ed., 1967, p. 143.

(21) Sabemos que a existência de uma consciência central, matizada e individualizada, é essencial para a relação aristotélica de fruição. Por isso, não é arbitrário verificar seu apogeu romanesco na forma narrativa consagrada pelo século XIX. 
ficação da forma artística que cristalizou e completou a ideologia dos andantes? Dito em outros termos: seria possível descobrir em $D$. Quixote sinais efetivos de uma subversão da relação de leitura proposta nas novelas medievais? A pergunta parecerá menos apressada se lembrarmos que a gama de preocupações temáticas de $D$. Quixote está centrada na pessoa do leitor da novela cavalheiresca. Quem é D. Quixote, e qual é a sua loucura, senão a figura ideal desta relação de leitura privilegiada na epopéia de cavalaria, onde o leitor se deixa enredar nas astúcias do ilusionismo e lhe paga o tributo da alienação do seu bom senso? D. Quixote não é, afinal de contas, da primeira à ultima página, a personificação do leitor que não traz os livros à mão, mas carrega-os na lembrança, condenado perpetuamente à sua relação de leitura, destrinçando os sinais do mundo de acordo com a letra dos livros?

De início, entretanto, D. Quixote parece consagrar a relação de leitura caçoada na figura do Quixote-leitor: durante todo o primeiro volume, não há sinais contundentes de que se esteja ensinando ao leitor de $D$. Quixote uma leitura estranha à leitura quixotesca do herói. É certo que o tom do "cronista" deste livro que lemos não é o mesmo dos seus (supostos) modelos medievais. D. Quixote, de fato, experimentará uma decepção indignada ao ler o registro de suas façanhas, porque, desde o princípio, ele traz projetado o ideal do seı cronista e espera dele que escreva:

"Yendo, pues, caminando nuestro flamante aventurero, iba hablando consigo mesmo y diciendo: 'Quién duda, sino que en los venideros tiempos, cuando salga a luz la verdadera historia de mis famosos hechos, que el sabio que los escribiere no ponga, cuando llegue a contar esta mi primera salida, tan de mañana, desta manera: 'Apenas había el rubicundo Apolo tendido por la faz de la ancha y espaciosa tierra las doradas hebras de sus hermosos cabellos, y apenas los pequeños y pintados pajarillos con sus harpadas lenguas habían saludado con dulce y meliflua armonía la venida de la rosada Aurora, que, dejando la blanda cama del celoso marido, por las puertas y balcones del manchego horizonte a los mortales se mostraba, cuando el famoso caballero Don Quijote de la Mancha, dejando las ociosas plumas, subió sobre șu famoso caballo Rocinante, y comenzó a caminar por el antiguo y conocido campo de Montiel'?" (22) (D. Quixote, Vol. I, Cap. 2, p. 312.).

(22) As citações de D. Quixote serão feitas de acordo com as Obras Completas de Cervantes, Madrid, Aguilar, 1975, 18a. edição, Vol. II. 
A narração desta passagem foi, em verdade, menos lisonjeira. D. Quixote ganha o mundo através da "puerta falsa de un corral", assistido talvez pelo testemunho prosaico dos seus habitantes mudos. O cronista não poupa alusão à "mal compuesta celada" do herói e não toma precauções que proíbam o leitor de evocar a fuga sorrateira de um louco recolhido.

Este desmazelo do cronista, entretanto, não pretende minar a relação aristotélica de leitura consagrada nos textos de cavalaria. A maneira dos medievais, a recorrência do narrador ao discurso em primeira pessoa, que lhe confere pouco a pouco uma onisciência autoral cada vez mais ampla, deve apenas garantir o estatuto de autenti. cidade à sua narrativa. De fato, é através deste truque que o leitor é avisado de que D. Quixote é uma figura pública, historiada por muitos autores, cujas aventuras estão transcritas nos anais da Mancha e das quais o narrador de $D$. Quixote é apenas um dos tantos autores. "En un lugar de laMancha, de cuyo nombre no quiero acordarme", lê-se de saída na abertura do romance: é certo que o leitor menos desavisado poderá pressentir na declaração a advertência de que está à mercê de uma autoria, que seleciona as aventuras e diz o que bem entende. Mais à frente, entretanto, não poderá deixar de lhe depositar toda a confiança possível, seduzido pelo cuidado com que discute a discordância dos autores acerca da primeira aventura de D. Quixote, ou a insistência em referir a disputa em țorno do nome de fidalgo do herói: Quijada, Quesada ou Quijano? O leitor não suspeita mais da autoridade e seriedade do cronista, confiante de que os fatos omitidos serão de menor relevância ainda:

Pero esto importa poco a nuestro cuento; basta que en la narración dél no se salga un punto de la verdad. (I, I, 309).

A apoteose deste artifício se dá a ler na digressão narrativa que principia no Capítulo VIII, quando o narrador suspende o desenlace de uma aventura por causa da carência de documentos que the garantam autenticidade. A perseverança e a casualidade, entretanto, permitem que o cronista tope em Alcaná de Toledo com um manuscrito árabe versando sobre as aventuras do cavaleiro, que contém não apenas a continuação da batalha interrompida, mas também uma ilustração da pendência, "pintada muy al natural", fixada no próprio momento em que os autores suspendem a narrativa. Desde então, El Ingenioso Hidalgo Don Quijote de la Mancha, "siguiendo la traducción", será escrito a partir da Historia de Don Quijote de la Mancha, de Cide Hamete Benengeli, historiador árabe. Mas a honestidade do novo historiador espanhol não permite que fiquem na sombra certas restrições que o leitor deve ter em mente em relação ao documento consultado: 
$\mathrm{Si}$ a esta se le puede poner alguna objeción acerca de su verdad, no podrá ser otra sino haber sido su autor arábigo, siendo muy propio de los de aquella nación ser mentirosos, aunque, por ser tan nuestros enemigos, antes se puede entender haber quedado falto en ella que demasiado. E ansí me parece a mí, pues cuando pudiera y debiera extende: la pluma en las alabanzas de tan buen caballero, parece que de industria las pasa en silencio. (I, 9, 337).

Somente a partir destes senões, produtos da avareza de um historiador politicamente interessado e a quem não se poupam insultos, é que o narrador dará continuidade às façanhas de D. Quixote, não esquecendo as referências que o isentam da narrativa e conferem à história seus foros de verdade: "cuenta el sabio Cide Hamete Benengeli...".

A partir de uma certa altura, entretanto, depois de ter instalado o leitor neste espaço seguro, Cervantes passa a introduzir com insistência, por entre a previsibilidade das aventuras quixotescas, certos episódios que, se não subvertem radicalmente a relação de leitura até então proposta, ao menos põem em dúvida a clareza de articulações estabelecidas entre narrador, personagens e leitor.

Sabemos que no Volume II, dada como suposta a publicação da primeira parte do texto de Cide Hamete Benengeli e vindas a público as aventuras apócrifas sob o nome de Alonzo Fernández de Avellaneda, as personagens do livro de Cervantes assumem com frequência o papel de leitores de ambos os Quixotes. Os textos são medidos pelo que contêm de verdadeiro e mentiroso; D. Quixote é a verdade em pessoa e, sem dúvida, o mais apaixonado dos leitores.

E certo que já na primeira parte do livro a narrativa tinha aberto um precedente neste caminho. Quando do escrutínio levado a cabo na biblioteca do herói, o leitor descobria com divertimento - $\mathrm{c}$ não sem uma certa estranheza - que D. Quixote guardava entre seus livros uma edição da primeira parte da Galatea de Cervantes. O Cura se declara então amigo e leitor de Miguel de Cervantes, este nome que a capa do livro que lemos traz impresso, e que por uma espécie de acordo bem conhecido supúnhamos ausente dele desde a Dedicatória.

A partir do Capítulo III da segunda parte, entretanto, não apenas o nome de Cervantes passa a figurar ilegalmente no outro lado da nossa condição de leitores. O livro inteiro também se exibe do lado de lá. Está aqui, ao alcance dos nossos olhos e da nossa liberdade de fechá-lo e reconduzi-lo à estante, mas está também entre as mãos de D. Quixote, Sansón Carrasco e D. Ālvaro, cujos dedos po- 
dem folheá-lo com a mesma preguiça ou a mesma paixão. O leitor se surpreende divertido perante esta ciranda repentina que define novos lugares, mas não pode conter um gesto meio sem graça quando se lembra que as personagens deveriam se deixar escrever sem se dar por isso. Em verdade, o sorriso amarelo do leitor (e é isto o que Borges declara) vem da estranheza de ter sido equiparado às personagens.

Mas não é possível deixar de aludir aos efeitos contrários produzidos pela circulação destes episódios por entre as aventuras de D. Quixote. A metáfora da equiparação revela, então, a sua utilidade, pois ela parece jogar ao mesmo tempo com a ambiguidade da nossa condição de leitores (lugar empírico que vira as páginas e lugar "transcendental" que assume um papel) e com a ambiguidade da narrativa quixotesca (estas peripécias inventadas que fingem ser escritas de acordo com coisas acontecidas). Neste sentido, podemos perscrutar o movimento da equiparação e perguntar sobre quem perde e quem ganha com o seu funcionamento. E o leitor, de fato, quem ascende (ou é rebaixado) à condição de ficção, como as personagens, ou o que se pretende, em verdade, é trazer as personagens à condição empírica do leitor, inculcando-lhes uma verdade e uma realidade cada vez menos sujeitos à dúvida? O que estamos perguntando, com efeito, é se a multiplicação destes episódios procura sacudir a embriaguez do leitor, curando-a por meio de um certo distanciamento, que o chama para a realidade da leitura e lhe proíbe o caminho da leitura experimentado pelo Quixote-leitor: ou se põem em funcionamento artifícios mais ousados, trazendo a literatura para o livro com a intenção de conferir-lhe mais verdade e tornar mais eficaz a relação de identificação .

Optar mecânicamente por uma ou outra destas direções talvez não seja tão legítimo quanto assumir a realidade de um conúbio, no mesmo lugar, destes efeitos contrários. O que Cervantes estaria pretendendo, ainda e sempre, não passaria de diversão e brincadeira, trazendo o leitor de um plano a outro, indefinidamente, advertindo-o para a sua condição de leitor, mas enredando-o em seguida, outra vez, neste jogo cujas regras são deixadas cuidadosamente à sombra. Faz-se do leitor o que, en verdade, ele é, uma ficção, mas, ao mesmo tempo, exige-se dele que esqueça esta verdade simples e acredite que a própria ficção é real Entretanto, na repetição destas idas e vindas em que a narrativa diverte o leitor à custa dele mesmo, a prática da leitura proposta pelas novelas de cavalaria se deixa ver pelo avesso e exibe seus limites. O jogo romanesco perdeu em certeza e segurança.

Acreditamos, portanto, ser legítimo advertir para esta diversidade escandalosa inscrita na prática do romance segundo D. Quixote. 
Anunciada desde o Prólogo de 1605, a desqualificação ideológica das novelas de cavalaria não implica, de imediato, numa recusa da relação de leitura proposta por elas. Apesar da stáira, Cervantes repōe em circulação os mesmos mecanismos de leitura, de tal maneira que, num certo sentido, $D$. Quixote se dá a ler como epopéia de cavalaria às avessas - a última destas novelas, como o próprio $\mathrm{D}$. Quixote crê. Num segundo momento, entretanto, não sem uma certa dose de imprevisto, o leitor se surpreende apeado do espaço seguro que lhe estava destinado. Instala-se num lugar mal definido pelas regras do romance, a partir de onde torna-se problemático determinar se a ficção é real ou se o real é ficção. Cervantes traz o leitor à sua condição empírica, através do desmascaramento da sua condição de ficção, mas, num só e mesmo gesto, borra o traçado nítido entre estas fronteiras ao trazer (por outros caminhos) as próprias personagens para este lado empirico das coisas. De qualquer maneira, o que assistimos aqui é o estilhaçamento desta prática da leitura consagrada nos textos medievais, onde os papéis estão distribuídos com clareza desde o início, onde o leitor esquece a sua empiricidade - este "ter o livro nas mãos" - através da aceitação, despercebida, de um certo papel no jogo ficcional do livro.

\section{V}

Tudo isto nos remete de novo à idéia do texto sujeito a retificações e a uma prática de escritor excluída dos ditames pré-estabelecidos da criação divina: a harmonia destes termos não se ajusta a $D$. Quixote. Acreditamos, entretanto, poder arriscar uma hipótese que explique menos abstratamente esta ambiguidade de leitura proposta pelo D. Quixote, explicação que, de resto, apenas reafirma esta idéia da literatura como prática exposta ao imprevisto.

A hipótese é de que talvez o livro de Cervantes mereça ser lido em três etapas, o que comportaria, entre o primeiro e o segundo volume, uma pausa. Esta pausa deve dar lugar à leitura do seu impostor, o Don Quijote el Malo de Avellaneda, a quem não apenas a cronologia das publicações parece ter conferido este lugar de intermediário entre a primeira e a segunda parte de Cervantes.

De fato, as repercussões do texto apócrifo na estrutura do Quixote autêntico são bem menos superficiais do que podem parecer. Menéndez Pidal dá bem a medida desta importância ao declarar:

"Mas eis que a obra deste serviu de fonte de inspiração para Cervantes quando escreveu a segunda parte de seu romance. Creio que Cervantes teve alguma notícia bastante detalhada da obra do seu competidor antes de redigir o capítulo LIX, onde já 
alude expressamente a ela, e que marca o momento em que ela veio a público. O certo é que Cervantes parecer ter querido sacar o fruto mais razoável da inveja que Avellaneda alimentava contra ele: o não assemelhar-se em nada com o seu invejoso; parece que nele Cervantes viu mais às claras que nunca os perigos de trivialidade e grosseiria que a fábula encerrava, e se esforça mais em eliminá-los ao redigir e segunda parte do Quixote. Já não se lhe poderá ocorrer dar aquelas duas ou três grossas pinceladas da primeira parte, ainda que já andassem tâo longe da rusticidade do seu imitador. A superioridade da segunda parte do Quixote, inquestionável para mim e também para a maioria, pode ser atribuída em muito a Avellaneda. Há fontes inspiradoras por repulsão, que têm tanta importância, ou mais, que as que operam por atração." (23).

Esta fonte negativa advertiria Cervantes para os sentidos do seu livro: dá-lhe com mais força a medida dos traços a sublinhar e dos caminhos a evitar. Deparado com a loucura do Quixote impostor, concebida segundo o "modelo do entremez" (24), Cervantes fugirá vigorosamente da recorrência a esta resolução: mais do que nunca, D. Quixote não renunciará agora à sua própria personalidade, "firme e erguida frente à dos heróis que o enlouquecem" (25). O próprio Sancho se afastará cada vez mais da figura do glutão escravizado pelos imperativos do estômago; em sua boca, a partir de então, surpreendemos o recurso a citaçõ̃es poéticas, fenômeno que obriga o tradutor de Cide Hamete a duvidar da autenticidade de certas passagens.

A partir da existência destas retificações, segundo Menéndez Pidal incompreensíveis se não se leva em conta o influxo imediato do texto de Avellaneda, podemos nos perguntar se não seria legítimo supor que, também em função desse influxo, Cervantes viu com mais clareza as implicações contidas na sua proposta de desqualificação ideológica da cavalaria andante. Desde o prólogo, com efeito, Avellaneda confessa a identidade de propósito em relação ao texto de Cervantes:

... tenemos ambos un fin, que es desterrar la perniciosa licción de los vanos libros de caballerías, tan ordinaria en gente rústica y ociosa. (Prólogo, p. 24) (26).

(23) MENENDEZ PIDAL - Ob. cit., pp. 41-2.

(24) Referência ao Entremés de los Romances, escrito por volta de 1591, e que pretendia satirizar os leitores de Romanceros. Possuido, entretanto, pela figura do herói, este louco abdica de sua própria personalidade, como D. Quixote na aventura do Capítulo V, primeira parte. MENENDEZ PIDAL, $O b$. cit., p. 24. 
A recusa deste "perniciosa lição", entretanto, não implica numa ruptura com a relação de leitura que a promove, o que expõe o leitor a ser atacado pelo mesmo mal que o livro desqualifica. Avellaneda recorre a novas fontes, "el sabio Alisolán, historiador no menos verdadero que moderno" (legitimado, de resto, no próprio Cervantes, que multiplicou os autores), resolve a disputa em torno do nome do herói, optando por Quijada e tece com paciência, da primeira à última página, a mesma malha da representação que secou o juízo do Quixote. O que pretendia, contudo, era denunciar a loucura do fidalgo,

efecto maldito de los nocivos y perjudiciales libros de fabulosas caballerías, dignos ellos, sus autores y lectores, de que las repúblicas bien regidas igualmente los desterrasen de sus confines. (VI, 24, p. 231).

Este desterro, parece, Cervantes passa a levá-lo efetivamente a termo a partir de Avellaneda.

LUIZ FERNANDO FRANKLIN DE MATOS

São Paulo, Dezembro de 1975 - Abril de 1976.

(26) As citações de Avellaneda serão feitas de acordo com El Ingenioso Hidalgo Don Quijote de la Mancha, Barcelona, E. Zeus, 1968, 1a. ed. 